\title{
Prevention of Violent Radicalization and Extremism in Finland: The Role of Religious Literacy
}

\author{
Marja Tiilikainen and Tarja Mankkinen
}

\begin{abstract}
The chapter explores how authorities in Finland have dealt with religion, in particular Islam, on the policy level with respect to the prevention of violent radicalization and extremism. We understand religious literacy as a kind of sensitivity among the authorities to religion and religious communities, in particular when discussing and dealing with such complex phenomena. The chapter is based on the analysis of two national action plans for the prevention of violent extremism, in particular on how Islam and Muslims are addressed in these plans, including during their preparatory phase. In addition, we draw on the extensive experience of the second author with security-related issues at the Finnish Ministry of the Interior. Finnish authorities have been very careful not to frame violent radicalization as a phenomenon that would be linked to one religion or ideology only. They also promote participatory governance in order to bring partnerships with Muslims and other faith communities into governance structures and prevent violent radicalization. This participatory approach can be explained not only by sensitivity to religion, but also by some other contextual factors typical to Finland.
\end{abstract}

Keywords Religious literacy • Participatory governance $\cdot$ Islam • Muslims • Prevention of violent radicalization $\cdot$ Action plan $\cdot$ Finland

\section{Introduction}

The terrorist attack in New York in September 2001 was a turning point in the development of securitization policies in the West as well as in the activation and emergence of violent political movements both locally and globally. During the past fifteen years, terrorist groups have used Islam to justify the violence, and as a consequence, many Muslims and non-Muslims alike have suffered from the violence

M. Tiilikainen ( $\varangle)$

Migration Institute of Finland, Turku, Finland

e-mail: marja.tiilikainen@migrationinstitute.fi

T. Mankkinen

Ministry of the Interior, Helsinki, Finland

(C) The Author(s) 2020

T. Sakaranaho et al. (eds.), The Challenges of Religious Literacy,

SpringerBriefs in Religious Studies, https://doi.org/10.1007/978-3-030-47576-5_6 
of these groups. Moreover, violent far-right ideologies and movements in Europe have grown and become more visible. In addition to groups that base their ideology on the national-socialist ideology and ideas of race, the number of anti-immigrant and antiIslam groups has increased. Therefore, life for the people who practice Islam has in many ways become difficult, as their religion is often seen as being synonymous with violence and, as a result, they face Islamophobia in their daily lives (e.g. Bayrakli and Hafez 2018). Since 9/11, a generation of young Muslims has grown to adulthood in a context where Islam is often seen as an enemy of the Western world and its values. At the same time, as religion has become part of the ideological and political battles and is actively being used as a tool to achieve different goals, the question of what kind of knowledge authorities should have on the role of religion in complex situations (see also Francis et al. 2015) and how they should consider freedom of religion in practice has become more important and sensitive than perhaps ever before.

The events of 9/11 escalated the global war on terror and the related development of securitization politics and counter-terrorism programmes aimed at increasing national security (Wæver 1995). In particular, Muslims in the "West" were framed as a threat or as "suspect communities" (Hickman et al. 2011), and their movements, connections and possible radicalization came under surveillance. According to Cesari (2012), as Muslims were constructed as an existential threat to the political community, it simultaneously justified exceptional measures of securitization. Moreover, security concerns in Europe resulted in a paradox involving, on the one hand, a desire to facilitate the integration of Muslims, and on the other, a perceived need to restrict the liberties of the Muslim populations (Cesari 2012, 437). Hence, authorities and civil servants need to make decisions regarding how to prevent violent radicalization and extremism, while at the same time there is a need to promote tolerant multicultural societies and nurture trusted relationships with stigmatized and securitized communities.

In this chapter, we will explore how authorities in Finland have dealt with religion, in particular with Islam, on the policy level with respect to the prevention of violent radicalization and extremism. We will utilize the concept of religious literacy (Dinham and Francis 2015), which we understand here as a kind of sensitivity among the authorities to religion and religious communities, in particular when discussing and dealing with such complex phenomena. In addition, religious literacy can be seen as an understanding of the larger contexts underlying violent radicalization and a willingness to ask more questions (see also Francis et al. 2015). Religious literacy entails an idea of having at least some knowledge about different religious traditions, but it primarily is a civic endeavour that supports the formation of a cohesive and inclusive society (Dinham and Jones 2010, 6).

In addition to a sensitivity to and awareness of religion, we are also interested in the participation of religious communities in the development of policies directed against violent radicalization. It has been noted that Muslims are increasingly included in the different sectors of governance, and partnerships are being built between civil society and the government (DeHanas et al. 2010). However, little reflection has taken place on the role and participation of Muslim communities in counter-radicalization and counter-terrorism activities (Spalek and Lambert 2008). 
The chapter is based on an analysis of two existing national action plans for the prevention of violent extremism in Finland, in particular on how Islam and Muslims are addressed in these plans, including during their preparatory phase. In addition, we draw on the extensive experience of the second author with issues related to security and extremism at the Finnish Ministry of the Interior. It is important to keep in mind that the role of the second author has been instrumental in planning and writing the national action plans, and hence, the analysis can also be regarded as self-reflective to some extent. The first author has written the chapter as part of a research project "Young Muslims and Resilience", funded by Kone Foundation.

\section{The Finnish Context}

Finland has not remained outside the above-described European and global developments, even if the debates and policies related to security first emerged in Finland later than in many other European countries. One reason for this lag is that Finland, especially compared to other Western European countries, has remained populationwise quite homogenous. The change began at the beginning of the 1990s when immigration to Finland started to increase. At the same time, the number of Muslims also increased as many asylum seekers and refugees from majority Muslim countries in Africa and the Middle East migrated to Finland. The first notable group was Somalis fleeing the civil war in Somalia since 1990. They were not the first Muslims in Finland, however, as a small Tatar Muslim community has existed in the country for more than a hundred years - a Tatar mosque was built already in 1942. The Tatar community has maintained its religious and cultural traditions, but at the same time members of the community have become well-integrated with mainstream Finnish society, the community is small (approximately 1000 people) and the people generally remain quite invisible for the general public (Sakaranaho 2002). Another group of Muslims in Finland are those who have converted to the Islamic faith, but also they are small in number. Therefore, the public debate surrounding Islam in Finland has primarily focused on the fairly recent Muslim populations, most of whom often have a refugee background, in particular the Somalis, but since the 2010s also Iraqis and Afghanis. The estimated number of Muslims in the country is approximately 100,000 people, including the children of Muslim migrants.

The number of Finnish people who belong to the Evangelical Lutheran Church of Finland has been decreasing, but still almost $71 \%$ of the Finnish population were listed as members of the church in 2017 (Evl 2018). In general, religion in Finland is perceived as a private matter and the society is secular, but at the same time church is part of cultural family rituals, such as weddings, and it also has a role in many official events, such as the opening ceremonies of parliament. The first Freedom of Religion Act was passed in 1922. The rapid institutionalization of Islam in Finland since the 1990s has been driven by the need to become publically recognized and approved. In addition, migrant associations have played a central role in the implementation 
of various projects aimed at integration, and thus, they have been necessary partners for public administration officials (Martikainen 2014, 93-95).

The increasing presence and visibility of religious minority groups, Muslims in particular, in the public sphere and institutions has challenged Finnish authorities to consider how to strike a balance between already existing practices, on the one hand, and religious needs and rights on the other. The Finnish debates taking place along the "migrant integration-security nexus" have until quite recently mostly followed the developments elsewhere in Europe (Martikainen 2019, 32-33). The influx of asylum-seekers in 2015 sparked a vocal debate on possible security risks related to (mostly male) migrants, sexual violence, terrorism and support for militant jihadists in Syria.

The general attitudes of Finnish people towards Islam have been predominantly negative. For example, in a recent survey $62 \%$ of Finns - the highest score among the 15 Western European countries studied-responded that "Islam is fundamentally incompatible with [Finnish] culture and values" (Pew Research Centre 2018, 66). At the same time, Finnish authorities have considered collaboration with the Muslim communities to be of central importance, and they have supported the founding of representative Muslim organizations in Finland, in particular the Islamic Council of Finland (SINE) in 2007. SINE was funded by the government until 2014, when the funding was cut due to financial misreporting (see Martikainen 2019).

\section{Preventing Violent Radicalization in Finland-The First Steps}

Despite the fact that since WWII Finland had been almost entirely free of political violence of either international or domestic origin, the country started to gradually develop strategies to prevent violent radicalization, driven by EU-level counterterrorism policies (Archer and Malkki 2012). The government of Finland has so far introduced three Internal Security Programmes (in 2004, 2008, 2012) aimed at enhancing security and safety broadly in different sectors of society. For example, the latest programme focuses on preventing and finding solutions to security concerns in everyday life, including homes, public spaces and work environments. In addition, "acts arising from extremist ideologies" are mentioned, along with school shootings (Ministry of the Interior 2012a, 55). School shootings have been a far more common concern for Finnish authorities than terrorism-the first incident regarded as a terrorist homicide or an attempted homicide under the terrorist law that came into force in 2003 only occurred in Finland as recently as August 2017, when a Moroccan asylum seeker killed two people and wounded several others in the city of Turku.

In 2012, the government of Finland adopted the first National Action Plan for the prevention of violent radicalization and extremism, and thus followed the steps of other Nordic countries. The title of the plan, "Towards a Cohesive Society", indicated 
its basic ideas: the plan and its measures targeted all forms of violent extremism existing in Finland, not only religiously motivated violent radicalization.

Until publication of the National Action Plan, knowledge about violent extremism and radicalization in Finnish society was quite limited. The Finnish Security Intelligence Service (SUPO) was the best-informed authority in this area, whereas the level of knowledge and awareness among local police was quite narrow. SUPO was responsible for counter-terrorism, whereas it was not entirely clear who was responsible for the prevention of violent extremism and radicalization-a task that was quite new at the time the first National Action Plan went into effect. According to the Action Plan, "effective, preventive action requires extensive collaboration among authorities and cooperation with civic society" (Ministry of the Interior 2012b, 20). At the same time, however, the Action Plan mostly focused on the work of authorities, leaving the role of non-governmental organizations and communities quite vague.

The National Action Plan describes the radicalization process only in general terms without making a distinction between different forms of violent extremism. Religiously motivated violent extremism is discussed in parallel with, for example, separatist extremist thinking and right/left-wing extremism. Moreover, possible challenges regarding religion and Islam are not specifically addressed. The Action Plan also highlighted the fact that violent radicalization is not a community-level problem, but rather an individual-level problem in Finland (Ministry of the Interior 2012b, 17). This can be regarded as a balanced approach, especially when taking into account the situation in 2012 during which time many other countries, such as Denmark, the Netherlands and the UK, were mainly focusing on radical Islamist extremism and terrorism. On the other hand, even the knowledge of experts about religion and its role in the radicalization process was limited and, in general, contacts with the religious communities were minimal.

One of the objectives of the Action Plan was to increase knowledge and information about violent extremist movements and ideologies among experts and the general public. The Action Plan also included information about the situation and preventive measures in other European Union member states and Nordic countries. One measure in the Action Plan was to publish a situation overview on violent extremism twice a year based on the information received from authorities. The report is an open document that describes the phenomenon and related developments in a comprehensive manner without providing details about individual people.

Another measure in the Action Plan was to hold regular roundtable discussions with the media. Topical themes related to the prevention of extremism have been discussed in these meetings, including such topics as whether media attention increase the popularity of and support for the violent extremist movements; travelling from Finland to the conflict zones in Syria and Iraq; what terminology should be used when talking about violent radicalization and extremism; and polarisation and violent radicalization. Hence, one of the aims of the Action Plan was to improve communication and collaboration between the authorities and the media, as well as to ensure that the media had enough background information on the complex topic.

All the main elements and issues that are still regarded as priorities with respect to the prevention of violent radicalization were already included in the first Action 
Plan: the importance of cooperation, of trust in the democratic system, of including young people in the democratic processes, and of balanced communication. The concrete measures, however, were strongly led by the authorities and the role of non-governmental organizations as well as communities was limited. This situation developed differently in the next phase.

\section{Moving Forward-The Second Action Plan}

The second National Action Plan for the prevention of violent radicalization and extremism was prepared and adopted in 2016 (Ministry of the Interior 2016). This time, in addition to the authorities, representatives of select non-governmental organizations and communities were also involved in drafting the plan. In general, the level of awareness regarding the importance and sensitivity of religious issues had increased since the first Action Plan. There were several reasons for this change. First, knowledge about the complex role of religion in radicalization and extremist ideologies had increased (see also Francis et al. 2015). Second, based on the experiences with the first Action Plan, it was quite clear that non-governmental and religious organizations should be involved in drafting and implementing the plan. The third important reason was the cooperation agreement that was signed in December of 2014 between the Ministry of the Interior and Finn Church Aid. As part of the cooperation agreement, Finn Church Aid and the Ministry of the Interior organized a study visit to Washington and Minneapolis in the USA in spring 2015. The Finnish participants on the visit were imams, representatives of the Lutheran Church and Jewish community, and authorities from the Finnish Ministry of the Interior, Ministry of Economic Affairs and Employment, National Police Board, Helsinki City and the Helsinki Police Department as well as from the Finn Church Aid. Also, some young Muslims participated in the trip. The programme for the visit was comprehensive, including several meetings with representatives from religious communities in the USA. In addition, the discussions and interactions between the members of the group during the visit guided the future writing of the Action Plan.

Consequently, the second Action Plan was drafted in broad cooperation with authorities representing the government and municipalities, some religious and other organizations, and individual people, among others. Muslim communities also had the possibility to discuss the content of the plan and give their feedback. For example, the second author of this chapter visited different mosque communities and Muslim organizations and presented a draft of the Action Plan. The participants and communities had the chance to provide immediate feedback on the draft and also send their written comments afterwards. Like the first Action Plan, the second Action Plan also targeted all forms of violent extremism in Finland, not only religiously motivated radicalization (Ministry of the Interior 2016, 14). Therefore, the feedback from the Muslim communities was crucial in order to make sure that the Action Plan did not stigmatize the Muslims. This was an area where the knowledge and experience of the Muslim communities were needed. The Action Plan does not mention Islam per se; 
instead, the plan refers to, for example, the conflict in Syria and Iraq and to people who have travelled from Finland to the combat zones (ibid., 13). Furthermore, not only mosques, but also churches and synagogues, are mentioned as religious communities that should be included in, for example, cultural and global education at schools and as places where students could visit to increase understanding and dialogue between different religious groups (ibid., 27).

In Finland, the role of religious communities in the prevention of violent extremism is regarded as highly important. According to the Action Plan: "Religious communities can strengthen people's participation, social interaction and spiritual life. They can mutually support each other and take action if religion is being hijacked as a justification for violence" (Ministry of the Interior 2016, 14). In addition, the Action Plan states the following regarding the capacity of the religious communities to prevent violent radicalization: "Religious communities are experts and credible actors in matters related to religious interpretation. Religious communities can support individuals and groups that counter the recruitment of violent factions. They also play an important role in strengthening the communities' resistance to violence-inducing propaganda. Working together, religious communities can act against violence and spread the message that violence can never be justified on the basis of religion" (ibid., 18).

Based on the Action Plan, certain measures in which religion and religious actors had a central role were initiated. For example, the Reach Out project (2016-2019) was launched by Finn Church Aid. The objective of the project was to establish a close-knit community uniting the authorities, organisations, various communities and religious actors to work together under the umbrella of preventing violent radicalization and extremism. As part of the project, the participants received intensive support for their efforts at curbing violent radicalization and extremism. These activities included, for example, seminars held in different parts of Finland involving authorities and representatives of Muslim communities. In addition, authorities were provided support in issues related to religion, and mothers whose children had been radicalized and travelled to/died in Syria were provided with support as well. The goal was to make everyone's expertise and experiences available and to spread the knowledge about available services and best practices in different municipalities and regions in Finland. From the authorities' point of view, an important result of the project was the increased cooperation between authorities and religious communities and, through this collaboration, increased awareness of the role of religion in violent radicalization. In addition, direct contacts with key persons in religious communities who might be consulted when needed were created.

In general, knowledge about world religions among Finnish authorities is limited, and therefore, there is a need for expertise regarding religious traditions, those of Islam and Judaism in particular: these religions are currently seen as priorities by authorities since Islam is used as a justification for violence at the same time as anti-Semitism is increasing. Jewish communities in general are well networked and they have efficiently advanced issues relevant for them in Finnish society, whereas Muslim communities are less organized and they have been more passive (apart from the Tatars) in relation to working with authorities and the state. At the same time, 
cooperation between the Lutheran Church and different authorities has a long history, and often even one based on law. For example, priests and pastoral care are available in prisons and hospitals. The diaconal work of the Lutheran church is well-integrated in the field of social work in Finland and provides multi-faceted practical help with various problems that people may have in life. In addition, the Church is invited to give statements when new laws and other issues are being prepared that will impact its activities and field of operations. Muslim communities do not automatically have this opportunity. In addition to the lack of representation and organization, one likely challenge to greater collaboration and interaction during the past years has been the fact that the Finnish authorities have primarily seen Muslim communities through the lens of terrorism and violent radicalization, and therefore, their interest has been more problem-orientated.

Another example of a measure where religious communities have an important role is the so-called Shoulder to Shoulder project, coordinated by Finn Church Aid, which aims to combat hate speech and the hate crimes experienced by religious communities. The aim of the action is to develop ways that religious communities can use to support each other when threatened or attacked. Different activities include, for example, holding joint events for different religious communities, staging peace walks, making joint statements and providing visible support to those communities that experience such a threat (e.g. cleaning graffiti off the walls of sacred buildings together). This measure aims to decrease mistrust and conflicts between different religious groups, such as Shia and Sunni Muslims as well as Jews and Muslims. Terrorist groups such as ISIL have capitalized on the tensions between Jewish and Muslim communities in their propaganda, and therefore, the kinds of inter-religious dialogues and activities that support mutual trust are considered important.

\section{Finnish Policies Against Violent Radicalization: Lessons on Religious Literacy?}

Based on our reading of the Action Plans for the prevention of violent radicalization and extremism in Finland, it can be observed that the authorities have been very careful in their choice of wording so as not to frame violent radicalization as a phenomenon that could be linked to one religion or ideology only. In fact, the word "Islam" is not mentioned in the documents at all. Sensitivity for not stigmatizing Muslim, or any other religious community, can be considered as a token of the increased level of religious literacy, but also as a necessary step towards engaging and collaborating with faith communities in the future for the common good.

The authorities have also made a conscious effort to engage religious communities in the planning of the second Action Plan as well as preventative work, which will likely be reflected in the final outcome. Throughout the process, the authorities have also signalled that religion is not regarded as a threat, but as an asset in such common efforts. One possible reason for this approach might be the long history of 
cooperation between the Lutheran Church and the authorities. This makes it perhaps easier also for other religious communities to cooperate with authorities, and vice versa. In addition, the neutrality of the Finnish state in relation to religious matters (Martikainen 2014) has probably helped the incorporation of religious communities in efforts at collaborating with the authorities. At the same time, however, it must be noted that many Muslims are relatively new to Finland and the community is heterogeneous, and therefore not well-organized, which has an impact on the opportunities for Muslims to influence decisions that concern them. The small size of the country and possibilities for non-hierarchical communication with authorities in general, in addition to the general level of societal security and trust, are other contextual factors that facilitate collaboration between authorities and religious communities.

In Finland, collaboration between authorities and religious communities is even included as a strategic guideline in the new police strategy on preventive work (Ministry of the Interior 2018). Hence, Finnish authorities promote participatory governance (DeHanas et al. 2010, 6-7) in order to bring partnerships with Muslims and other faith communities into existing governance structures and to prevent violent radicalization. This is not the case in all EU countries, however, and there are also differences between the Nordic countries. For example, in Finland and in Sweden civil society organizations and religious communities are actively involved in national efforts to prevent violent extremism, whereas in Norway and in Denmark they are not given specific roles in the preventative strategies (Ramboll 2017).

The Nordic countries signed a cooperation agreement in January 2015 to exchange experiences and develop common methods for preventing violent radicalization. Cooperation in research is also included in the agreement. Because of this close cooperation, religious issues as well as collaboration between religious organizations and communities are also regularly discussed. In Denmark, however, the civil servants working in the ministries are advised to avoid contacts with religious communities, which means that they are not able to ask for advice from religious communities nor invite representatives from the communities to meetings or events. In the worst case scenario, this strategy may lead to the development of parallel societies and decrease the sense of belonging among some minorities. It may also convey a message that religions are a threat to the society.

In Finland cooperation across different sectors, and between ministries, researchers, professionals and civil society, seems to be easier and less hierarchical than in many other countries. One reason for this may be the relatively long history of associations (including migrant associations) working together with public authorities through the implementation of various projects (Martikainen 2014). In addition, social cohesion is still quite strong and societal trust high. According to the Eurobarometer (2017), the level of trust in public administration among the Finnish people (together with people from Luxembourg) was the highest in the EU (77\% of the population). Ninety-four per cent of Finns reported that they trust the army (the highest score among the studied EU countries) and $91 \%$ the police. Studies among people with a migrant background in Finland show similar trends. According to one population study, people with a foreign background reported that they for the most part trust-even more than the native-born population-the social and health care 
services, the judicial system and the police: for example, $82.8 \%$ of them claimed they trust the police, whereas the respective number among the native-born Finnish population was $74.6 \%$ (Castaneda et al. 2015, 18-19).

In the European Union, efforts at preventing violent radicalization and extremism are continuously developing, and it is one of the top priorities in the area of justice and home affairs. In June 2018, the ministers adopted a proposal (European Union 2018) regarding the European Union's priorities in the area, including a proposal to develop related structures and mechanisms. The European Union's priorities in matters of policy also include recommendations regarding religious issues. One priority area has to do with prisons and probation, rehabilitation and reintegration, and one of the recommendations is to increase the exchange of experiences on how best to provide religious counselling in prisons and to provide guidelines on working with and training chaplains, particularly imams, for prison and probation settings.

Cooperation with religious communities is also supported by the European Union. In the priority area of local and multi-agency approaches, the recommendation is to identify good practices and guidance for local cooperation in the preventative work taking place between local agencies and non-governmental organizations, including faith communities. Another priority area is ideology and polarization, where the recommendation to the member states is to establish a joint overview of the different approaches and experiences and explore possible further actions in relations with religious leaders, communities and institutions, including the training of religious leaders, pluralism, faith-related dialogues, funding and the monitoring of religious institutions spreading a militant Islamist ideology.

Even though the level of knowledge regarding different religious traditions and groups among authorities who work at preventing violent radicalization and extremism in Finland is, in general, pretty low, the opportunity to collaborate with religious communities greatly helps them overcome any gaps in information and understanding. On the level of national strategies and action plans, such as the National Action Plan for the Prevention of Violent Radicalisation and Extremism (Ministry of the Interior 2016) and the new police strategy on preventative work (Ministry of the Interior 2018), this collaboration is encouraged and even obligatory. In addition, the wording and frameworks laid out in the action plans are important tools for authorities and grass-root level professionals and they will help pave the way for good practices and respectful and non-stigmatizing encounters, where both the rights and needs of the religious communities as well as concerns for national security may be approached and taken into account.

Regardless of the limited knowledge about world religions and religious traditions, Finnish authorities have been aware of the need to consider the role of religion in public sphere, in particular in supporting societal cohesion and preventing violent radicalization and extremism (see also Dinham and Jones 2010, 6). At the same time as it has been acknowledged that "religion matters", religion has been largely perceived as a collective phenomenon that has been approached through religious communities. Hence, less attention has been paid to understanding intra-religious diversity, which should also be recognized as part of religious literacy. 
In this chapter, we have described the increased collaboration and partnerships with Muslim communities, in particular through the experiences and viewpoints of the authorities. In the future, research will need to reflect more the views of Muslim communities regarding participation in counter-radicalization activities (see Spalek and Lambert 2008). Listening to and assessing Muslim voices regarding participation and representation as well as the dynamics and possible tensions between different actors and power positions would be a needed step in developing the idea of religious literacy further and what it could practically mean in the prevention of violent radicalization and extremism.

\section{References}

Archer, T., \& Malkki, L. (2012). Miten terrorismin ja radikalisoitumisen vastaisesta toiminnasta tuli tärkeä kysymys Suomessa? In T. Martikainen \& M. Tiilikainen (Eds.), Islam, hallinta ja turvallisuus (pp. 79-107). Turku: Eetos.

Bayrakli, E., \& Hafez, F. (Eds.). (2018). European Islamophobia Report 2017. Ankara, Istanbul, Washington D.C, Cairo: SETA.

Castaneda, A., Larja, L., Nieminen, T., Jokela, S., Suvisaari, J., Rask, S., et al. (2015). Ulkomaalaistaustaisten psyykkinen hyvinvointi, turvallisuus ja osallisuus. Ulkomaista syntyperää olevien työ ja hyvinvointi -tutkimus 2014 (UTH). Helsinki: THL. Retrieved November 11, 2018, from http://www.julkari.fi/bitstream/handle/10024/127023/URN_ISBN_978-952-302535-6.pdf?sequence=2.

Cesari, J. (2012). Securitization of Islam in Europe. Die Welt des Islams, 52(3/4), 430-449.

DeHanas, D. N., O’Toole, T., Modood, T., \& Meer, N. (2010). Researching Muslim participation in contemporary governance: A brief introduction. Muslim Participation in Contemporary Governance. Working Paper, No. 1. Centre for the Study of Ethnicity and Citizenship, University of Bristol.

Dinham, A., \& Francis, M. (2015). Religious literacy: Contesting an idea and practice. In A. Dinham \& M. Francis (Eds.), Religious literacy in policy and practice (pp. 3-25). Bristol: Policy Press.

Dinham, A., \& Jones, S. H. (2010). Religious literacy leadership in higher education: An analysis of challenges of religious faith, and resources for meeting them, for university leaders. York: Religious Literacy Leadership in Higher Education Programme.

Eurobarometer. (2017). Standard eurobarometer 88. Report. Public opinion in the European Union. Survey requested and co-ordinated by the European Commission, Directorate-General for Communication. European Union.

European Union. (2018). High-level commission expert group on radicalisation (HLCEG-R). Final Report, 18 May 2018. Luxembourg: European Union. Retrieved December 21, 2018, from http:// ec.europa.eu/transparency/regexpert/index.cfm?do=groupDetail.groupDetail\&groupID=3552.

Evl. (2018). Seurakunnat tilastoivat työtään. Suomen evankelis-luterilainen kirkko. Retrieved November 9, 2018, from https://evl.fi/tietoa-kirkosta/tilastotietoa.

Francis, M., van Eck, A., \& van Twist, D. (2015). Religious literacy, radicalization and extremism. In A. Dinham \& M. Francis (Eds.), Religious literacy in policy and practice (pp. 113-134). Bristol: Policy Press.

Hickman, M. J., Thomas, L., Silvestri, S., \& Nickels, H. (2011). 'Suspect Communities'? Counterterrorism policy, the press, and the impact on Irish and Muslim communities in Britain. A Report for Policy Makers and the General Public. London Metropolitan University.

Martikainen, T. (2014). Muslim immigrants, public religion, and developments towards a postsecular Finnish welfare state. Tidsskrift for Islamforskning, The Nordic Welfare State, 8(1), 98 105. 
Martikainen, T. (2019). The founding of the Islamic council of Finland. In T. Martikainen, J. Mapril, \& A. Hussain Khan (Eds.), Muslims at the margins of Europe. Finland, Greece, Ireland and Portugal (pp. 27-44). Leiden: Brill.

Ministry of the Interior. (2012a). A safer tomorrow: Internal security programme. Ministry of the Interior publications 40/2012. Helsinki: Ministry of the Interior. Retrieved November 10, 2018, from http://julkaisut.valtioneuvosto.fi/bitstream/handle/10024/79479/sm_402012.pdf.

Ministry of the Interior. (2012b). Towards a cohesive society: Action plan to prevent violent extremism. Ministry of Interior publications 33/2012. Helsinki: Ministry of the Interior.

Ministry of the Interior. (2016). National action plan for the prevention of violent radicalisation and extremism. Ministry of the Interior publications 17/2016. Helsinki: Ministry of the Interior. Retrieved November 11, 2018, from http://julkaisut.valtioneuvosto.fi/bitstream/handle/10024/ 75040/Kansallinen_vakivalt_radikalisoituminen_eng_NETTI.pdf.

Ministry of the Interior. (2018). Enska. Poliisin ennalta estävän työn strategia 2019-2023. Helsinki: Sisäministeriö. Retrieved December 21, 2018, from https://valtioneuvosto.fi/artikkeli/-/asset_pub lisher/1410869/poliisin-uusi-strategia-siirtaa-painopistetta-ennaltaehkaisyyn.

Pew Research Center. (2018). Being Christian in Western Europe. Retrieved April 2, 2019, from https://www.pewforum.org/2018/05/29/being-christian-in-western-europe/.

Ramboll. (2017). Efforts to prevent extremism in the Nordic countries: Mapping. Denmark: Ramboll. Retrieved November 11, 2018, from http://uim.dk/publikationer/efforts-to-prevent-ext remism-in-the-nordic-countries.

Sakaranaho, T. (2002). Kansamme tuntematon väestönosa. Suomalaisten tataarimuslimien julkisuuskuva. In T. Sakaranaho, \& H. Pesonen (Eds.), Uskonto, julkisuus ja muuttuva yhteiskunta (pp. 132-159). Helsinki: Yliopistopaino.

Spalek, B., \& Lambert, R. (2008). Muslim communities, counter-terrorism and counterradicalisation: A critically reflective approach to engagement. International Journal of Law, Crime and Justice, 36, 257-270.

Wæver, O. (1995). Securitization and Desecuritization. In R. D. Lipschutz (Ed.), On security (pp. 46 86). New York: Columbia University Press.

Open Access This chapter is licensed under the terms of the Creative Commons Attribution 4.0 International License (http://creativecommons.org/licenses/by/4.0/), which permits use, sharing, adaptation, distribution and reproduction in any medium or format, as long as you give appropriate credit to the original author(s) and the source, provide a link to the Creative Commons license and indicate if changes were made.

The images or other third party material in this chapter are included in the chapter's Creative Commons license, unless indicated otherwise in a credit line to the material. If material is not included in the chapter's Creative Commons license and your intended use is not permitted by statutory regulation or exceeds the permitted use, you will need to obtain permission directly from the copyright holder.

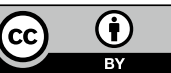

